\title{
KEBIJAKAN PENGETATAN PENJATUHAN PIDANA PENJARA SEBAGAI UPAYA MENGATASI OVERCAPACITY DI LEMBAGA PEMASYARAKATAN
}

\author{
Oleh : Joejoen Tjahjani, S.H, M.H.
}

Fakultas Hukum Universitas Islam Lamongan

\begin{abstract}
ABSTRAK
Over capacity atau kelebihan beban yang yang terjadi di lembaga pemasyarakatan di Indonesia merupakan persoalan yang ada sejak dahulu. Overcapacity terjadi karena laju pertumbuhan penghuni lapas tidak sebanding dengan sarana hunian lapas. Faktor pendorongnya adlah factor hukumnya lebih berorientasi pada pidana institusional(penjara), yang berdampak ada rendahnya tingkat pengawasan dan terjadinya prisonisasi. Hal tersebut tidak hanya menurut pandangan masyarakat tetapi juga aparat penegak hukum, terbukti dari sekitar 358 tindak pidana umum di tahun 2013 (hasil penelusuran di putusan.mahkamahagung.go.id), hanya terdapat 1 (satu) putusan yang menuntut terdakwa dengan pidana pokok denda walaupun pada putusannya majelis hakim memutus bebas. Overcapacity di samping terjadi di Lapas juga terjadi di Rumah tahanan (Rutan), berkaitan dengan tidak adanya ketentuan yang mengatur mengenai alasan yang dapat dibenarkan untuk dikabulkannya penangguhan penahanan sebagaimana diatur dalam Pasal 31 KUHAP sehingga semuanya berdasarkan subjektifitas pejabat yang berwenang. Selain itu tidak ada ketentuan yang mengatur jumlah uang yang harus dibayar oleh terdakwa atau tersangka sebagai jaminannya terkait dikabulkannya penangguhan penahanan dengan jaminan uang. Hal ini menambah rumah tahanan (Rutan) di polres maupun di polsek. Aparat penegak hukum jarang menjadikan pidana denda sebagai bentuk pemidanaan. Selain itu, bentuk putusan yang kumulasi pidana penjara dengan pidana denda, telah menambah beban lembaga pemasyarakatan karena hampir semua narapidana memilih menjalani pidana subsidair dengan tambahan penjara atau kurungan daripada mebayar pidana denda. Dengan semua tuntutan maupun putusan memutus pidana penjara maka jumlah narapidana untuk lembaga pemasyarakatan semakin membesar.
\end{abstract}

Kata kunci : kebijakan, pidana penjara, menanggulangi, overcapacity narapidana

\section{PENDAHULUAN}

Kementerian Hukum dan Hak Asasi Manusia (Kemenkumham) menyatakan jumlah penghuni lapas mencapai 214 ribu narapidana (napi) pada Maret 2017. Menkumham Yasonna Laoly mengusulkan adanya hukuman alternatif bagi napi untuk mengurangi overcapacity lapas.

Sampai saat ini Rutan Bagansiapiapi dinobatkan sebagai tempat pembinaan nara pidana paling padat di Indonesia. Bayangkan saja, pasalnya kelebihan kapasitas yang ada di rutan ini sudah mencapai $800 \%$ dari jumlah yang seharusnya. Para warga binaan di rutan tersebut ada yang berstatus tahanan maupun narapidana. Yang membedakan yaitu yang berstatus tahanan belum divonis dipengadilan sedangkan narapidana sudah divonis. Akibatnya mereka harus hidup secara seadaanya di tempat rutan ini karena memang tidak ada pilihan lain lagi. Dampak kelebihan jumlah pelanggar hukum sebagai penghuni rutan maupun lapas yang tidak sesuai dengan daya tampung, menimbulkan overcapacity yang mengakibatkan rendahnya tingkat pengawasaan dan keamanan. Pengawasan 
Jurnal Independent Fakultas Hukum yang rendah dapat memicu berbagai permasalahan seperti perkelahian antar napi, kaburnya napi, tidak maksmialnya proses pembinaan, tingginya tingkat kriminalitas di lapas seperti maraknya kasus narkoba di lapas.

Salah satu faktor penyebab terjadinya kerusuhan di Lembaga Pemasyarakatan Tanjung Gusta, Medan, beberapa waktu lalu adalah kurangnya daya tampung penjara (overcapacity). Jumlah narapidana di lapas tersebut mencapai 2.600 orang, sementara kapasitas lapas hanya 1.054 narapidana. Lebih lanjut menurut Yasona untuk mengurangi overcapacity lapas adalah dengan remisi bagi para napi, sekitar 50 persen penghuni lapas adalah pelaku kejahatan narkoba. egara lain menerapkan pengampunan napi untuk mengurangi overcapacity lapas. "Beberapa negara lain pakai pengampunan, amnesti yang sudah menjalani beberapa tahun". Akibat overcapacity lapas, Kemenkumham harus menanggung sekitar Rp 200 miliar hanya untuk anggaran konsumsi napi. Karena itu, Yasonna mengatakan masih mengkaji soal usulan lapas atau rutan yang dikelola swasta.

Menurut Penjelasan umum UU No. 12 Tahun 1995, yaitu dalam hal melaksanakan sistem pemasyarakatan , diperlukan juga peran serta masyarakat, baik dengan mengadakan kerja sama dalam pembinaan maupun dengan sikap bersedia menerima kembali warga binaan pemasyarakatan yang telah selesai menjalani pidananya. Dalam hal pembinaan, narapidana bukanlah obyek melainkan subyek yang tidak berbeda dari manusia lainnya yang dapat melakukan kesalahan atau kekhilafan yang dapat dikenakan pidana, sehingga tidak harus diberantas. Yang harus diberantas adalah faktor-faktor yang dapat menyebabkan Narapidana berbuat hal-hal yang bertentangan dengan hukum, kesusilaan, agama,atau kewajiban-kewajiban sosial lain yang dapat dikenakan pidana.

Permasalahan penelitan yang diajukan berkaitan dengan overcapacity narapidana di lembaga pemasyararakatan, yaitu: a. Kebijakan pengetatan penjatuhan pidana atau model lembaga pemasyarakatan yang sesuai yang dapat mengatasi dampak negatif overcapacity di lapas.

b. Peran serta masyarakat dan aparat penegak hukum dalam mendukung pelaksanaan system pemasyarakatan yang berspektif HAM untuk wujudkan tujuan pemidanaan.

Tujuan khusus dilakukan penelitian ini adalah dapat memberi kontribusi pemangku kepentingan untuk membuat kebijakan yang berbasis HAM bagi napi di lapas dan untuk memberikan sumbangsih dari sisi akademik untuk mengatasi persoalan dampak negatif overcapacity narapidana di Lapas. Urgensi pemilihan tema penelitian ini adalah banyaknya kasus narapidana yang melarikan diri dari rumah tahanan maupun dari lembaga pemasyarakatan, sehingga perlu dipikirkan alternative untuk tidak mengobral putusan pidana penjara bagi pelanggar hokum.

\section{METODE}

Tipe penelitian ini adalah penelitian hukum (legal research) yaitu suatu penelitian untuk menemukan aturan hukum, prinsip-prinsip hukum, maupun doktrin-doktrin hukum yang relevan dan melakukan telaah mengenai konsep-konsep hukum, pendapat para ahli hukum untuk meningkatkan daya interpretasi guna menjawab isu hukum yang dihadapi.

Pendekatan yang digunakan dalam penelitian ini adalah pendekatan perundang undangan (Statute Aprroach), pendekatan konseptual (conceptual approach) dan pendekatan kasus (Case Approach). Statute Approach adalah pendekatan berdasarkan peraturan perundang- undangan dilakukan dengan menelaah semua undang-undang dengan regulasi yang bersangkut paut dengan isu hukum yang sedang ditangani. Penelitian ini bertitik tolak dari peraturan perundang-undangan dengan menekankan pada pencarian norma yang terkandung dalam ketentuan peraturan perundang- 
Jurnal Independent Fakultas Hukum

undangan. Conceptual approach ialah pendekatan yang beranjak dari pandangan dan doktrin-doktrin yang berkembang didalam ilmu hukum. Sedangkan Case Approach yaitu pendekatan kasus dengan menelaah kasus-kasus putusan pengadilan yang berkekuatan hukum tetap.

\section{PEMBAHASAN}

Istilah penjara adalah istilah yang digunakan oleh sebagian besar masyarakat awam di Indonesia untuk memaknai tempat menjalani hukuman bagi pelanggar hukum, entah masih belum diputus proses dakwaannya di pengadilan (calon terhukum) ataupun sudah diputus proses dakwaannya di pengadilan. Penjara juga memberi stigma bagi mereka yang pernah menjadi penghuninya, yang artinya suatu tempat untuk orang-orang yang harus membayar kejahatannya, yang oleh masyarakat dicap sebagai "bukan orang baik baik. Sejak diundangkannya UU No.12 Tahun 1995 tentang Pemasyarakatan istilah penjara kemudian digantikan dengan istilah lembaga pemasyarakatan dengan konsep pembinaannya untuk menggantikan konsep pembalasan yang terdapat pada sistem kepenjaraan. Lapas atau Lembaga Pemasyarakatan atau disingkat LP adalah tempat untuk melaksanakan pembinaan terhadap narapidana dan anak didik pemasyarakatan di Indonesia.

Lembaga Pemasyarakatan (Lapas) merupakan institusi dasi subsistem peradilan pidana mempunyai fungsi strategis sebagai poelaksanaan pidana penjara dan sekaligus tempat pembinaan narapidana sebagaimana diatur dalam Undang Undang No.12 Tahun 1995 tentang Pemasyarakatan. Persoalan mendasar yang dihadapi di semua lapas di Indonesia adalah kelebihan hunian (overcapacity) narapidana. Over capacity Lapas merupakan suatu keadaan saat warga binaan pemasyarakatan melebihi kapasitas suatu Lapas. Masalah overcapacity ini dialami hampir di seluruh lapas di Indonesia. Menurut penjelasan Andi Matalata bahwa pada Tahun 2008 penghuni lapas di seluruh Indonesia mencapai 130.882 orang dengan rincian
54 tahanan dan 76.525 napi. Jumlah tersebut tidak seimbang dengan kapasitas lapas yang hanya mampu menampung 81.384 orang. Artinya terjadi overcapacity mencapai $45 \%$.

Secara teoritik overcapacity dalam lembaga pemasyarakatan dapat menimbulkan prisonisasi. Sykes dalam "pains of imprisonment Theory" menegaskan bahwa pada hekikatnya prisonisasi terbentuk sebagai respon terhadsap masalah-masalah penyesuaian yang dimunculkan sebagaui akibat pidana penjara itu sendiri dengan segala bentuk perampasan (depriviation).

Pandangan Sykes didukung oleh Steven Box, bahwa prisonisasi adalah suatu adaptasi yang dilakukan oleh napi atas kepedihan dan penderiataan tertentu dalam penjara. Menurut Box hakikat seorang napi yang baru masuk adalah merupakan bagian dari sebuah segitiga. Sudut pertama adalah organisasi atau wakil-wakil resmi atau norma petugas, sudut kedua adalah kelompok napi yang menawarkan penyelesaian berbagai macam masalah diantaranya mengatasi suatu perampasan yang merupakan penderitaan.

Implikasi negative prisonisasi berakar dari kenyataan dimana system social napi sangat mendukung dan melindungi napi yang sangat mendalami pola tingkah laku criminal dan sebaiknya akan sangat tidak mendukung bahkan menindas atau mengancam napi yang masih menunjukkan loyalitas pada dunia non criminal. Menurut Bernes dan Teeters bahwa pejara telah tumbuh menjadi tempat pencemaran yang pada hakikat justru penyokong-penyokong penjara dicoba untuk dihindari sebab tempattempat ini penjahat-penjahat kebetulan (accidental offenders) dirusak melalui pengalaman-pengalamannya dengan penjahat kronis. Bahkan personil yang baikpun telah gagal untuk menghilangkan keburukan yang sangat besar dari penjara.

Sebagai bahan perbandingan upaya melakukan reformasi (perbaikan dari si terpidana) itu maka pidana penjara menurut sistem Irlandia tersebut dijalani melalui tiga tingkatan, yaitu.

Page|153 
Jurnal Independent Fakultas Hukum

a). Tingkatan pertama (probation), si terpidana diasingkan dalam sel malam dan siang hari selama delapan atau Sembilan bulan satu tahun. Lamanya pengasingan di sel itu tergantung kepada kelakuan si terhukum.

b). Tingkatan kedua (public work prison), si terhukum dipindahkan ke satu penjara lain dan penjara lai itu ia diwajibkan bekerja bersama dengan si terhukum lainnya. Biasanya si terhukum di dalam penjara dibagi dalam empat kelas. Si terhukum untuk pertama kali menjalani pidananya ditempatkan pada kelas terendah dan secara berangsur-angsur dipindahkan ke dalam kelas yang lebih tinggi sesudah ia memperoleh beberapa perlakuan yang lebih baik dikarenakan perbuatannya patut mendapat imbalan yang setimpal, dengan menggunakan sistem sesuai dengan "mark system".

c). Tingkatan ketiga (Ticket of leave), si terhukum dibebaskan dengan perjanjian dari kewajibannya untuk menjalani dari sisa waktu lamanya pidana.

Penelitian yang dilakukan Center for Detention Studies (CDS) menemukan fakta bahwa overstaying merupakan fenomena yang biasa terjadi di hampir setiap rutan dan lapas. Dengan meneliti 11 unit pelaksana teknis lapas dan rutan di lima provinsi, CDS menunjukkan sejumlah sebab overstaying, antara lain keterlambatan ekstrak vonis dan eksekusi putusan. Di Lapas I Medan misalnya CDS menemukan 16 dari 71 tahanan yang sudah melebihi masa tahanan. Tiga orang diantaranya sudah melewati masa penahanan 600 hari. Di Jakarta, gambaran yang nyaris sama ditemukan CDS. Di Rutan Kelas I Jakarta Pusat tercatat 159 tahanan yang mengalami overstaying. Penelitian CDS menemukan tiga faktor penting penyebab overstaying, yaitu faktor regulasi, keterlambatan administrasi dan geografis, serta faktor individu narapidana.

\section{KESIMPULAN}

Permasalahan yang terjadi dalam rangka pembinaan narapidana di lapas kelas I dan kelas IIA dengan adanya overcapasity diperlukan adanya solusi bagi pemangku kepentingan mengenai upaya upaya yang dapat dilakukan untuk mengatasi persoalan overcapacity di lapas dengan berbagai kebijakan seperti pengetatan penjatuhan pidana atau model lembaga pemasyarakatan yang tepat yang dapat mengatasi dampak negatif overcapacity.

Disamping itu perlunya peningkatan peran serta masyarakat dan aparat penegak hukum dalam mendukung pelaksanaan system pemasyarakatan yang berspektif HAM untuk wujudkan tujuan pemidanaan.

\section{REFERENSI}

1. Angkasa, Overcapacity Napi di Lapas, "Faktor Penyebab, Implikasi Negatif serta Solusi dalam upaya Optimalisasi Pembinaan Napi", Jurnal Dinamika Hukum , Vol.10 No.3 September 2010, h. 1

2. eip.or.id/permasalahan-penyebabkelebihan-jumlah-narapidana-dilembaga- pemasyarakatan

3. Badan Pembinaan Hukum Nasional Kementrian Hukum dan Hak Asasi Manusia Republik Indonesia: 2010, Penangguhan penahanan bagi koruptor, Jakarta: hal 31

4. http://news.okezone.com.

5. Prisonisasi adalah istilah yang diciptakan Donald Clemer yang dikonsepkan sebagai the taking on, in grater or lesser degree, of the folkways, more, custums and general culture of penitentiary" ( Stanton Wheeler, "socialication in Corrections" dalam Sir Leon Radzinowich and Marvis E.Wolfgang(ed.) Crime and Justice, New York: Basic Book, Inc Publisherr, tanpa tahun, p. 194

6. Steven Box1981, Deviance, reality and Society, second ed., Holt, Rinchert and Winston, London, New York Sidney Toronto, h.216 
Jurnal Independent Fakultas Hukum

7. Romli Atmasasmita, 1983, Kepenjaraan dalam suatu Bunga Rampai, Bandung:Armico, h.48-49

8. Muladi dan Barda Nawawi Arief, 1984, Teori-teori dan kebijakan Pidana, Bandung: Alumni, h.79 